\title{
ACCOUNTING ASPECTS OF UTILITY RATE REGULATION
}

\author{
LLOYD J. KLEIN*
}

The rate making process is characterized by a wide variety of accounting determinations. The final expressions of the relative inadequacy, or excessiveness, of present rate schedules and the reasonableness of the proposed new tariffs are deceptive in their simplicity. Behind the final answer lies the area of accounts-the sales, the capital expenditures, the depreciation accruals, the return, and the operating expenses.

At times the treatment of accounts plays a singularly important part in rate determinations. Often the process is mechanical. Always the accounting evidence is voluminous, if not ominous.

While the emphasis on accounting in rate determinations differs widely from case to case and jurisdiction to jurisdiction, there are general areas in which issues invariably arise. A few of the most significant accounting problems are discussed hereinafter with the hope that the reader will be neither awed nor dismayed with the current status of these problems.

\section{RATE Base}

The development of a means of measurement of the reasonableness of rates is fundamental to judicial review of regulatory procedure. The function of a rate base is to provide one basis for such a measurement, and has long been required by the courts-from the opinion of Blatchford, J., in the Milwaukee Railway case ${ }^{1}$ in 1890 , through the Smyth case in $1898,{ }^{2}$ the Natural Gas Pipeline case in $1942,{ }^{3}$ to the Hope case in $1944^{4}$

In spite of the strenuous efforts of certain state commissions ${ }^{5}$ and the Federal Power Commission to minimize the importance of the validity of a rate base on the "end result" theory, a review of recent decisions by various state courts forcibly indicates that the right to judicial review as to the reasonableness of rates is being jealously guarded. ${ }^{\circ}$

The Illinois Supreme Court called attention to the fallacy of adopting a "bookkeepers" rate base consisting of merely depreciated original cost in the Illinois Bell

*B.S. 1946, J.D. I950, Northwestern University. Member of Illinois Society of Certified Public Accountants.

${ }^{2}$ Chicago, M. \& St. P. Ry. v. Minnesota, I34 U. S. $4^{18}$ (189o).

${ }^{2}$ Smyth v. Ames, 169 U. S. 466 (1898).

${ }^{3}$ Federal Power Comm'n v. Natural Gas Pipeline Co., 315 U. S. 575 (1942).

- Federal Power Comm'n v. Hope Natural Gas Co., 320 U. S. 59x (1944).

- For example, Commonwealth Telephone Co. v. Public Service Comm'n, 252 Wis. 481, 32 N. W. $2 \mathrm{~d}$ 247 ( 1948 ).

'Illinois Bell Telephone Co. v. Commerce Commission, 4I4 Ill. 275, III N. E. 2d 329 (1953); City of Marietta v. Public Utilities Comm'n, I48 Ohio St. I73, 74 N. E. 2d 74 (1947); Commonwealth Telephone Co. v. Public Service Comm'n, 252 Wis. 48 I, 32 N. W. 2 d 247 (1948). 
Telephone case. The Commission in that case claimed that the rate of return was one of the most important factors in fixing a rate base. The court, however, said: ${ }^{7}$

This statement at first blush has a deceptive quality of truth. Its best criticism is that it creates an inextricable circle, providing no beginning nor any basis for fixing a rate of return other than the nebulous formula "that when all things are considered the rate should be just and reasonable and provide a reasonable return on investment."

The net original cost base, which has been used exclusively by the Federal Power Commission since the Hope case, began as an accounting "refinement" or "reformation" by regulatory bodies in I937 with the promulgation of the Uniform System of Accounts for Electric and Gas Utilities.

While the requirements of this uniform accounting system at the time of its adoption were said to have certain advantages in providing comparative cost and financial data, no standards for application of these data have been built into the accounting system. This inflexibility combined with the tendency of regulatory bodies to promulgate regulatory theories under the guise of accounting refinements has seriously impaired the effectiveness of accounting in rate regulation. George O. May stated in this connection: ${ }^{8}$

Acceptance of some postulates of accounting, such as those of its utilitarian character and the stability of the monetary unit, and disregard of others, such as those of continuity and consistency, have resulted in the development of concepts of accounting new in the field in which they are applied, of which original cost and straight-line depreciation in the utility field are perhaps the most notable. If the procedure is challenged in the early stages the defense is that only methods of recording and no substantive rights are involved. But once the record is established it is made the basis of orders which affect rights but are in practice almost irreversible.

Prior to the Natural Gas Pipeline and Hope Natural Gas cases, regulatory agencies generally insisted that a system of accounts requiring original cost accounting could not be conclusive for rate purposes. ${ }^{9}$ Even during the period of intensified promotion of original cost accounting there was no real argument that original cost was synonymous with value. This fact was admitted by Mr. Charles W. Smith, Chief, Bureau of Accounts, Finance and Rates, Federal Power Commission, and a leading exponent of original cost, when he testified in the American Telephone case: ${ }^{10}$

It is my firm conviction . . . that . . o original cost . . is important not only from the viewpoint of original cost per se but also because it is an admirable check on the other evidences of value which are usually introduced in valuation proceedings. 336.

${ }^{7}$ Illinois Bell Telephone Co. v. Commerce Comm'n, $4 \times 4$ Ill. 275, at $287-288$, III N. E. $2 d$ 329, at

${ }^{8}$ May, Accounting and Regulation, 76 J. Accountancy 295, 297 (1943).

- The order of the New York Public Service Commission, which adopted its System of Accounts in 1927, contained a provision "that in presenting this system of accounts, the Commission does not commit itself to the approval or acceptance of an item set out in any account, for the purpose of fxing rates or in determining other matters before the Commission."

${ }^{10}$ American Telephone and Telegraph Co. v. United States, 299 U. S. 232 (1936). 
The advent of original cost accounting, however, provided the more sophisticated regulatory people with a basis for the appealing approach to regulation on "sound" accounting principles. The original cost advocates contended that the complexities and delays inherent in the controversial reproduction cost rate base were no longer necessary, since the then present-day original cost concept provided a sound basis for rate determination. All that remained was justification for the use of the results of such accounting as a basis of value for rate-making purposes.

The Natural Gas Pipeline and Hope Natural Gas cases incorporating the "end result" theory conveniently provided that justification. Original cost could now be construed as value and as a result, a NARUC Committee reporting to the $195^{2}$ convention on progress in regulation was able to state:

A rate base consisting of depreciated original cost or net investment plus working capital still receives exclusive or substantive weight in most final determinations.

The economic changes of the war and postwar period have sharply brought to light the inflexibility of the "original cost standard." If original cost were a measure of arriving at just and reasonable rates in the setting of the economic conditions of the thirties and early forties, how can it be a fair measure in the vastly changed conditions of today?

It is apparent that during a period of rising prices the common stockholder loses on two counts through the application of the original cost concept. First, real capital is not maintained intact because of the fact that the consumer pays rates that do not compensate for the value of property consumed in rendering service, while on the other hand the equity investor faces the prospect of providing new capital or taking on new partners to finance the high-cost property additions. Second, the shareholder loses because he invested full dollars in the business and receives in return half dollars in the form of dividends. The conclusion is inescapable that ratemaking on an original cost basis during a period of inflation and rising price levels necessarily results in inequities to the investor. The Federal Power Commission and certain of our state commissions, however, have been reluctant to recognize this situation. ${ }^{11}$ The attitude of certain commissions in this regard was clearly reflected by the New York Public Service Commission in the New York Telephone case. ${ }^{12}$ The Commission denied the Company's application for increased rates, because it did not believe that the legislature wished to protect investors in public utility securities from "the effects of policies of the national government." Furthermore, that Commission also stated that it did not wish to add the investors in the utility business to the "privileged classes" who are insulated against inflation, notably laborers and farmers.

12 "As far as Federal regulation is concerned, no recognition has yet been given to the shrinkage in the value of the dollar, and the old rules of measuring rate base and allowances for capital exhaustion by unadjusted 'original costs' continue to be applied. In fixing the rate of return no express attempt has been made to compensate for the lack of adjustments in rate base and return figures." Dean, The Impact of Changing Price Levels in Rate Making, 52 P. U. FORT. 8I9 (I953).

${ }^{12} \mathrm{Re}$ New York Telcphone Co., 9I P.U.R. (N.s.) 23I, 248 (r952). 
There are, however, several indications that the inequities and fallacies of the narrow application of the original cost doctrine under present-day circumstances are beginning to be recognized. The courts rather than the commissions seem to be more aware of the equity in the fair value concept. The attitude of the Illinois Supreme Court was referred to previously. In 1950, the Michigan Public Service Commission in adopting a fair value rate base stated $:^{13}$

As we see it, the determination of fair value is a matter of judgment. It is to be exercised by the Commission after giving careful consideration to all the various elements entering into the formation of a sound, reasonable, and intelligent judgment as to the present fair value of the property of the utility used and useful in its business.

It appears that the fair value rule is also being followed in North Dakota, Ohio, Pennsylvania, and South Dakota. ${ }^{14}$ In New Jersey, Kentucky, Maryland, Minnesota, West Virginia, Rhode Island, Georgia, and Kansas the law requires that the rate base shall be determined by consideration of fair value; however, the commissions in these states have modified the traditional concept of fair value by giving predominant weight to original cost, or by using original cost as the sole measure of fair value. The current status of regulatory thinking on this issue was summarized by Mr. Paul Grady of Price Waterhouse \& Co., in an address at the thirty-fifth annual convention of the American Gas Association, St. Louis, Missouri, on October 27, I953:

While the trends there indicated are encouraging, a great deal remains to be done in obtaining a full understanding of the permanent impact on utility cost of the monetary inflation which has occurred in the past 20 years. All of the major factors in rate-making -namely, the rate base, the allowance for property exhaustion and the rate of return-are substantially affected. Substantial progress could be made if we can bring about an understanding that the primary issue is not so much fair value versus a prudent investment or cost concept, but rather that original cost is not a valid method of determining real economic costs after a substantial and permanent decrease has occurred in the purchasing power of the monetary unit.

Until it is generally recognized that rate-making philosophies cannot be relegated to a strict accounting basis, there will remain the ominous threat to realistic regulation-regulation which will sustain the growth of the utility business with fair and equal treatment to both the investor and consumer. An informed investor does not purchase stock in any company solely on the basis of its financial statements which today are prepared principally from a "stewardship" point of view. A regulatory agency which propounds regulation on such an accounting basis is ignoring the basic original concept of regulation, which is to perpetuate and develop private enterprise, not to destroy it.

\footnotetext{
${ }^{23} \mathrm{Re}$ Consumers Power Co., 82 P.U.R. (N.S.) 97, 108 (1950).

${ }^{14}$ Northern States Power Co. v. Public Service Comm'n, 73 N. D. 211, 13 N. W. $2 d 779$ (1944); City of Marietta v. Public Utilities Comm'n, I48 Ohio St. 173, 74 N. E. 2d 74 (1947); City of Pittsburgh v. Pennsylvania Public Utility Comm'n, I68 Pa. Super. 95, 78 A. 2d 35 (I95I); Equitable Gas Co. v. Pennsylvania Public Utility Comm'n, I6o Pa. Super. 458, 51 A. 2d 497 (1947); Re Northwestern Bell Telephone Co., 73 S. D. 370, 43 N. W. $2 d 553$ (1950).
} 
A. Specific Accounting Problems Involved in Determination of Rate Base

So great are the basic controversies over the development of a valid and equitable rate base in regulatory processses that certain accounting problems have been generally under-emphasized.

I. Capitalization of Interest During Construction. The basic principles underlying the capitalization of interest during construction are firmly established in regulated industry. Basically, interest is capitalized so that one of the costs applicable to construction will be recorded on the books of the company. It gives recognition to the fact that capital, the same as labor, must receive compensation for its services.

Although most uniform systems of accounts provide for interest during construction, ${ }^{15}$ there has developed a serious controversy in regulatory proceedings as to the amount of interest which is capitalizable. This controversy arises principally over (I) the interpretation of the word "interest" (which fundamentally entails determination of the rate at which interest should be capitalized), and (2) the period during which interest is capitalizable.

It has long been the practice of most utilities to capitalize interest during construction at a composite rate of 6 per cent, which gives effect to the cost of borrowed funds and the cost of equity funds devoted to construction. Methods of application vary-frequently a rate determined by giving effect to the above factors is applied to those construction expenditures, generally in excess of a fixed amount, which are in process of completion over a month-but the objective is to recognize the cost of capital while it is employed in the construction program.

The recent trend in the Federal Power Commission's thinking, however, has been toward a sharp reduction in the interest which it will allow utilities to capitalize on equity funds employed in construction. The Federal Power Commission staff's position, which has been approved by that Commission, and upheld by the courts, is that interest capitalized on equity funds may not exceed 6 per cent; and that interest may be capitalized at this rate only when such funds have been actually expended for construction purposes, and then only after all of the borrowed money has been expended.

The controversy over the rate at which interest should be capitalized revolves fundamentally around the question: "What is a reasonable rate to apply to the company's own funds utilized in construction?" in accordance with the provisions of the classification of accounts (Uniform System of Accounts ${ }^{16}$ ). In the Northern Natural case, ${ }^{17}$ the examiner held that interest on equity funds may be computed at a rate not to exceed 6 per cent since "it has been the policy of the Commission in

\footnotetext{
${ }^{15}$ Instructions, Gas Plant Accounts, Federal Power Commission, General Rules and Regulations, Unifora System of Accounts for Natural Gas Companies \$201.3-5(q) (1948), i 8 Code Fed. Regs. \$201.3-5(q) (1949): "Interest during Construction' includes the net cost of borrowed funds used for construction purposes and a reasonable rate upon the utility's own funds when so used."

${ }^{10}$ Federal Power Commision, General Rules and Regulations, Subchapter $F$, Uniform System of Accounts for Natural Gas Companies.

${ }^{17} \mathrm{Re}$ Northern Natural Gas Co., Docket Nos. G-1382, G-1533, and G-1607, 95 P.U.R. (N.s.) 289, 299 (1952).
} 
most cases to allow 6 per cent for the use of such funds...." No further reference was made as to the reasoning that 6 per cent represented a reasonable rate. However, the Federal Power Commission staff has repeatedly contended that "interest" on equity funds during construction should be limited to a nominal interest rate which is not related to the cost of common stock money-or a fair rate of return. ${ }^{18}$

It appears, however, that the logical test of a reasonable rate under any equitable standard should be the "cost" of those funds. To use less than a "reasonable rate" on the utility's own funds, which rate is the "cost" of the funds, is to claim that capital devoted to construction costs less than capital employed in operations. Such a position implies that there is less risk during the construction period than after operations commence, and that stockholders should be willing to accept a smaller return while construction is in progress. In reality, all the stockholder receives through capitalization of interest during construction is the opportunity to earn a return in the future after the property has commenced operation. If the equity owner is fully apprised of the extent to which his investment is lost through denial of return during the construction period, it must inevitably lead to a loss of investor confidence and a consequent higher cost of capital and the retrenchment of new construction. Equity capital, the same as debt, must be paid its full hire-a fair rate of return.

The second basic controversy in the application of interest during construction is the period during which interest is capitalizable. In the Northern Natural Gas case $^{19}$ the examiner stated:

Interest during construction on equity funds was allowed only from the date that all borrowed funds had been expended, despite the fact that additional equity funds had been acquired for construction purposes approximately six months prior to that time.

In referring to this restriction, the examiner stated:

It is not reasonable to allow a computed rate of interest on equity funds, while unused. ...

A realistic appraisal of the realities of financing clearly reveals the inherent inequities of such an approach. Disallowance of interest prior to actual expenditure of funds in effect is a mandate to management of "day to day" procurement of funds, a practice which is neither practical nor feasible.

In this connection it is interesting to note the contention of the Federal Power Commission staff relative to commitment fees under credit or purchase agreements. It has been repeatedly urged by the staff that such a fee, which is a fee paid by utilities to lenders for firm financial arrangements, is not a proper component of construction cost but a financing cost which should be amortized over the life of the bonds. The commitment fee is a nominal cost resulting from the arrangement for the availability of funds as needed through a construction period, in lieu of

\footnotetext{
${ }^{18}$ Federal Power Commission Brief, Re Northern Natural Gas Co., Docket Nos. G-1382, G-1533, and G-1607, stupra note I7.

${ }^{10} \mathrm{Re}$ Northern Natural Gas Co., Docket Nos. G-1382, G-1533, and G-1607, sutpra note 17.
} 
securing the entire proceeds of a bond issue with full interest charges prior to commencement of construction. It is an accepted accounting principle that such costs are not related to the bond issues as are ordinary financing costs incurred in the sale of bonds but are costs incurred in arranging for availability or "stand-by" of funds for construction. It would appear logical that nominal fees paid for the standby of funds would be accounted for in the same manner as interest on such funds should the funds be secured in their entirety at the beginning of construction. The position of the staff of the Federal Power Commission in respect to commitment fees, therefore, not only is contrary to accepted accounting principles, but in addition does not appear in agreement with their position relative to discouragement of advance procurement of funds.

It should also be noted that the disallowance of interest on equity funds prior to the expenditure of all borrowed funds also ignores practical financing realities. It is a well known fact that construction cannot be financed by borrowed funds alone, and that many indentures allow bond money to be withdrawn only after a specified percentage of construction has been completed with other funds.

2. Costs Incurred in Securing Certificates and Gas Purchase and Sales Contracts. There has been a divergence of opinion among accountants and regulatory personnel as to the proper accounting for costs incurred in connection with certain incidental costs of business.

In general, most major pipeline companies have capitalized costs of securing certificates of public convenience and necessity. An analysis of the nature of such certificates reveals their similarity to corporate charters, costs of which have clearly been established to be capitalizable. From an accounting standpoint, costs of obtaining certificates which authorize the performance of certain functions for which the utility was organized should properly be classified as intangible and thus be included in plant-in-service. If a period of time is specified in the certificate, it would be proper to amortize the cost over the period.

The policy in the industry regarding the accounting for costs incurred in securing gas purchase and sales contracts varies with the amount involved. From an accounting viewpoint, it would appear reasonable either to capitalize or defer such costs, the latter course being desirable only if there is a favorable expression from the Commission as to the allowance for the amortized portion of these costs in the cost of service, and for the unamortized portion in the rate base.

3. Purchase of Gas in Place. The present uncertainties as to the possible regulatory jurisdiction over sellers of gas to interstate natural gas pipeline companies have increased the difficulties in obtaining gas purchase contracts. Many companies in an attempt to surmount this difficulty and in order to assure future gas supplies are resorting to the purchase of gas in place.

There is no particular accounting problem with respect to recording the acquisition of gas in place except as to the implications that such accounting might have under regulatory proceedings. The original cost doctrine under the Uniform 
System of Accounts necessitates the determination of the date "first devoted to public service." In this connection, it must be considered that the cost of a producing well to the original owner is nominal compared to the value of the well which becomes, of course, the cost to the buyer.

It is clear that a broad interpretation of the Uniform System of Accounts for rate-making purposes would limit the purchasers to a return on the original cost of the reserve to the developer. The resulting restriction on a purchaser would tend to discourage exploration for future reserves to assure continuity of supply.

An additional problem encountered in the purchase of gas in place is the uncertainty as to regulatory attitude toward the classification of the future gas supply. It has been contended that such property is in reality "plant held for future use" and not includible in the rate base for rate-making purposes. It is further argued that present rate payers should not have to assume the cost of gas supply for future customers. Such contentions, however, fail to recognize that the assurance of future supplies is basic to present pipeline operations. In all certificate cases, companies are required to show a substantial reserve supply of gas. It is also important to note that disallowance of purchased gas in place should necessarily entitle gas companies to capitalize carrying costs, including a return on equity funds, on that portion of the investment which is considered held for future use.

4. Development Costs of Producing Properties. Costs incurred in the exploration and development of producing properties present some interesting and important problems to natural gas transmission companies owning producing properties. In designing the Uniform System of Accounts for natural gas companies, the Federal Power Commission has indicated that it was influenced to a large extent by the general practices of the gas and oil industry with respect to development costs. The gas and oil industry, however, was not subject to rate regulation and the industry practices were undoubtedly motivated to a large degree by tax considerations rather than by an interest in reflecting true capital costs.

The Uniform System of Accounts prescribed by the Federal Power Commission provides that nonproductive well drilling, delay rentals, and other nonproductive exploration and development costs are to be charged to current expenses and that amounts invested in acreage held for future use are to be capitalized.

From an accounting viewpoint, it appears more reasonable to consider such exploration and development costs as related to an accounting unit, i.e., a producing lease or field, as capital charges. These costs are generally incurred in efforts to define the limits of the pool and cannot be considered an operational cost relating to the day-to-day production from the field. Therefore, it appears only logical that these costs are capital costs relating to the entire producing area which should be expensed through depletion and depreciation.

From a regulatory standpoint, it might be argued that inclusion of such costs in the cost of service provides for immediate reimbursement of the investor by the consumer and therefore is a more practical method of treatment than capitalization 
which entails a return to the utility on its investment. The fallacy of this argument lies in the fact that, as a practical matter of operation, such costs are not uniform costs of production which apply to day-to-day deliveries. It is impractical operationally to spread such a development program evenly over the life of the producing property. In a rate proceeding, it becomes necessary to establish on an assumed basis an annual allowance for such a development program. Since realities do not result in such a uniform program, obvious inequities result either to the consumer or to the investor. Either the utility is required to make an investment upon which no return will be received should the program temporarily exceed the rate annually allowed in the rate proceeding or, assuming the program is less than the annual allowance, the consumer is in effect becoming an investor-a contributor of capital which could conceivably be utilized for other investment purposes.

It is important that consideration be given to this situation since there are several related items of cost which are not clearly classified in the Uniform System of Accounts and which receive a wide divergence of treatment within the industry. Such costs are plugged wells drilled beyond the producing horizon, deepening well costs, and certain geological and geophysical costs which under certain conditions should be considered as capital items.

5. Working Capital. Generally, the components of working capital requirements are materials and supplies, prepayments, minimum bank balances, allowance for cash operating expenses, gas in underground storage, and line pack.

There is general acceptance of allowance for 45 days' cash operating expenses (excluding cost of purchased gas), materials and supplies, and prepayments. ${ }^{20}$ The determination of cash operating expense is based on the assumption that customer receipts generally are received approximately 45 days after the services or product is produced and delivered.

In its early rate decisions, the Federal Power Commission consistently disallowed claims of natural gas companies for minimum bank balances in cash working capital for the reason that working capital allowances were liberal in the light of availability of tax accruals. ${ }^{21}$ Utilities subsequently accepted the directions of the Federal Power Commission and other regulatory decisions and did not contend for a minimum bank balance allowance.

More recently, however, the Federal Power Commission in Re Alabama-Tennessee Natural Gas Company ${ }^{22}$ reduced the company's claims for working capital requirements, which did not include minimum bank balances, by an amount calculated to be available from federal income tax accruals. Thereafter, in view of the

${ }^{20}$ In the Matter of Canadian River Gas Co. et al, 3 F. P. C. 32, 52 (1942); City of Cleveland v. Hope Natural Gas Co., 3 F. P. C. 150 , I74 (1942); City of Detroit v. Panhandle Eastern Pipe Line Co., 3 F. P. C. 273,282 (1942); In the Matter of Cities Service Gas Co., 3 F. P. C. 459,477 (I943); In the Matter of Mississippi River Fuel Corp., 4 F. P. C. 340, 344 (I945); In the Matter of Tennessee Gas Transmission Co., 6 F. P. C. II4, II5 (I947).

${ }^{21}$ In the Matter of Canadian River Gas Co. et al, 3 F. P. C. 32, 52 (1942); City of Detroit v. Panhandle Eastern Pipe Iine Co., 3 F. P. C. 273,283 (I942); Re Interstate Natural Gas Co., 3 F. P. C. 4I6, 425 (1943); Re Cities Service Gas Co., 3 F. P. C. 459, 478 (1943).

${ }_{22} 94$ P.U.R. (N.s.) 426 (1952). 
Commission's announced intentions, many utilities have contended for allowance for minimum bank balances in rate proceedings, and have reduced such balances by available income tax accruals.

The Commission staff, however, has stated that the earlier Commission decision relative to the availability of tax accruals was not confined to federal income tax accruals. In a recent proceeding, the staff has taken the position that, ${ }^{23}$

Assuming arguendo that Michigan Wisconsin had justified the minimum bank balances, we contend further that it should be nevertheless disallowed because of the presence of the large amount of ad valorem taxes in the revenues in advance of payment.

As was discussed in connection with minimum bank balances, the Federal Power Commission has long contended that consideration must be given to the availability of federal income tax accruals in determining an allowance in the rate base for working capital requirements. In all cases before the Federal Power Commission prior to 1942, such tax accruals were assumed to offset minimum bank balance requirements. Accordingly, neither element entered into the mechanical computation of working capital requirements.

In the Northern Natural case, ${ }^{24}$ the Federal Power Commission deducted from the working capital requirements 75 per cent of the income tax allowed for the test period because it was provided by customers to meet Northern's federal income tax liability long in advance of the time when the liability must be met. This position was upheld by the Court of Appeals. ${ }^{25}$

It is generally recognized that tax accruals are in fact a source of funds which may be and unquestionably are temporarily devoted to company use. The controversies arising out of the current application of this theory by the Federal Power Commission relate, first to the amount of accrual which can properly be used as an offset to working capital requirements, and, second, to the components of working capital which can be supplied by tax accruals.

The Federal Power Commission since the Alabama-Tennessee case has computed the amount of the accrual available based on a straight monthly average of accrual balances during the year. A number of state commissions have adopted similar principles. $^{26}$ While such practices may be applicable to certain utilities such as telephone companies with relatively stable monthly revenues, it is apparent that this basis cannot be applied to industries affected by seasonal fluctuations. In the natural gas industry, tax accruals are not earned ratably over the year. It would appear logical that any reasonable computation of available tax accruals for working capital purposes should give special consideration to the low point in the accrual balance as the maximum accrual available for offset purposes.

${ }^{23}$ Brief of Commission Staff Council, In the Matter of Michigan Wisconsin Pipeline Co., Docket Nos. G-r 678 and 1996 .

2495 P.U.R. (N.s) 289, 300 (r952).

${ }^{25}$ Northern Natural Gas Co. v. Federal Power Comm'n, 206 F. 2d 690 (8th Cir. 1953), 207 F. 2d 264 (8th Cir. 1953), cert. denied, 346 U. S. 922 (1954).

"For example, Chesapeake \& Potomac Telephone Co. v. Public Service Comm'n of Maryland, 95 P.U.R. (N.s.) I29 (Md. Cir. Ct., Sept. I5, I952). 
In this connection, it should be considered that there is considerable merit to the contentions that use of tax accruals as an offset to an allowance for working capital should be viewed with caution. Admittedly, there can be no assurance that the income of a company will remain at any constant level. Therefore, the assumption that a constant tax accrual is available is obviously false. Conceivably the financial position of a company forced by regulatory direction to rely on an unstable source of funds to meet cash requirements of day-to-day operations could be endangered.

The second basic controversy involved in the offset of federal income tax accruals against working capital relates to the components which may properly be offset. It appears to be the policy of the Federal Power Commission to offset all working capital requirements by available federal income tax accruals. The difficulties of the practical application of such a theory are apparent upon a closer examination of the components of working capital requirements. Certain items, such as materials and supplies and gas stored in underground storage, are semi-permanent non-cash investments. The turnover of material and supplies is relatively slow, particularly as related to gas stored in underground storage. Investments in these items are out of phase with the income tax accruals and, moreover, such investments are required prior to collection of revenue from the consumer.

It cannot be denied that availability of income tax accruals should be considered in connection with the determination of an allowance for working capital. However, in view of the stepped-up payment provisions included in the Revenue Act of I950, together with the inherent difficulties heretofore discussed, it appears that the availability of such accruals for working capital purposes has been given the theoretical rather than the practical approach.

\section{Cost of Service}

The determination of the cost of service which in turn determines the revenue requirements of the regulated utility involves the calculation of: operation and maintenance expenses incurred in rendition of service; depreciation and depletion allowance for property consumed in the rendition of service; taxes; return to the investor for use of money invested in the utility; and an allocation of utility plant, costs, and expenses to customers under separate jurisdictions.

The determination of this cost of service results in a multitude of controversies which have plagued regulatory proceedings since the passage of the Natural Gas Act. While all of these problems are worthy of some discussion, it is only feasible in this general review of the accounting aspects of rate regulation briefly to examine some of the more controversial issues.

\section{A. Pro Forma Operation and Maintenance Expenses}

The determination of the appropriate allowance for operation and maintenance expenses entails, in the words of the Federal Power Commission Regulations: ${ }^{27}$

\footnotetext{
${ }^{27}$ Federal Power Comm'n, General Rules and Regulations, Amended Rule 154.63(b)(3), effective July I, 1953 .
} 
... the most recently available actual experience, adjusted for changes . . . which are known and measurable with reasonable accuracy ... the twelve months' experience shall be adjusted to eliminate nonrecurring items, but this shall not preclude the replacement of the nonrecurring item with another of nonrecurring nature which the natural gas company anticipates will be realized, including the provision for the normalizing of such items as rate case expenses.

It is apparent that the application of these regulations in a rate proceeding necessitates basic assumptions and conclusions with which reasonable minds may differ. A review of recent Federal Power Commission proceedings reveals that the accounting for costs during the past period is subject to unnecessary scrutiny and that there exists an inherent tendency to give only token consideration to the future and to rely on the past accounting period, adjusted for nonrecurring costs.

Any allowance for pro forma adjustments with respect to known or anticipated changes in cost must conform to the Commission Regulations as to "known and measurable with reasonable accuracy." There has been general reluctance on the part of most commissions to determine a cost of service for a future period based on general forecasts or budgetary estimates, although admittedly rates are set for a future period. While contractual increases in costs such as wage increases and increases contained in gas purchase contracts are generally considered in the determination of expenses, proposed pro forma adjustments which could be considered conjectural have been consistently disallowed.

The recent actions of the states of Kansas and Oklahoma in establishing minimum wellhead prices for natural gas have presented additional problems in the determination of allowable operating expenses, which are deserving of special attention. Despite contentions of natural gas pipeline companies that the field price or actual field value of gas in the areas in which the pipeline as a producer produces gas should be considered in rate procedings, the Federal Power Commission, upheld by the courts, has consistently ruled that regulation must be made on a cost basis. ${ }^{28}$ The Court of Appeals in the Northern Natural case stated $:^{20}$

The law as established by the Supreme Court ... is that Congress has vested the power in the Federal Commission to regulate in the national interest the charges natural gas companies may make for the gas they sell in interstate commerce for resale and that in accomplishing the regulation the Commission is free from the compulsion of giving any weight to the element of value of the companies' gas at the well heads.

It should be noted, however, that although for all practical purposes recent rate decisions by the Federal Power Commission and by the courts have in fact required the application of the "cost basis" principle, this principle has not received unanimous approval. Commissioner Nelson Lee Smith of the Federal Power Commission has consistently contended for a re-examination of the cost basis approach

${ }^{28}$ Federal Power Comm'n v. Hope Natural Gas Co., 320 U. S. 59 I (1944); Colorado Interstate Gas Co. v. Federal Power Comm'n, 324 U. S. 581 (1945); Panhandle Eastern Pipe Line Co. v. Federal Power Comm'n, 324 U. S. 635 (1945).

${ }^{20}$ Northern Natural Gas Co. v. Federal Power Comm'n, 206 F. $2 d$ 690, 705 (8th Cir. 1953), cert. denied, 346 U. S. 922 (x954). 
to pricing natural gas produced by pipeline companies. ${ }^{30} \mathrm{Mr}$. Justice Jackson in the Colorado Interstate case stated: ${ }^{31}$

To let rate-base figures, compiled on any of the conventional theories of rate-making, govern a rate for natural gas seems to me little better than to draw figures out of a hat. These cases confirm and strengthen me in the view I stated in the Hope case that the entire rate-base method should be rejected in pricing natural gas, though it might be used to determine transportation costs. These cases vividly demonstrate the delirious results produced by the rate base method.

In this connection, another aspect to the problem of the treatment afforded gas produced by a pipeline from its own reserves is a provision of the Natural Gas Act. Section $I(b)$ of the Act, ${ }^{32}$ provides that the Act, "shall not apply to any other transportation or sale of natural gas or to the local distribution of natural gas or to the facilities used for such distribution or to the production or gathering of natural gas."

This claim of immunity of an integrated pipeline company from regulation of its gas production operations was raised in the Northern Natural case, and denied by the Court of Appeals. The court in that case cited the decision of the Court of Appeals for the District of Columbia in Wisconsin v. Federal Power Commission and Phillips Petroleum Company, ${ }^{33}$ wherein the court decided that it was the duty of the Federal Power Commission to regulate Phillips' charges for sales. The Commission had contended that Phillips' transportation in interstate commerce, together with its processing operations and sales of natural gas, "all constitute a part of its gathering business, or they are incidents of or activities related to such business so that such movements, processing and sales come within the exemption of production and gathering in Section $\mathrm{I}(\mathrm{b})$ of the Act."

The actions of the states of Kansas and Oklahoma in establishing minimum wellhead prices in the interests of conservation have sharply accentuated the problem of pricing gas produced from a pipeline's own gas reserves.

In the Northern Natural case, Northern contended that in order to give full validity and effect to the Kansas commission order, the Federal Power Commission was legally bound and required to attribute to the cost of gas produced, the minimum wellhead price established by the Kansas Commission. The Federal Power Commission and the Court of Appeals did not subscribe to this view. The attitude of Commission and the court is exemplified by Commissioner Smith who stated in a concurring opinion: ${ }^{34}$

The validity of the Kansas order is not in question here. Similar orders of the Oklahoma Corporation Commission have been upheld by the Supreme Court of the

${ }^{30}$ Re Northern Natural Gas Co., 95 P.U.R. (N.S.) 289, 315, 317 (1952).

${ }^{2}$ Colorado Interstate Gas Co. v. Federal Power Comm'n, and Canadian River Gas Co. v. Federal Power Comm'n, 324 U. S. 58r, 6ro (r945).

${ }^{32} 52$ STAT. 821 (1938), 15 U. S. C. \$717(b) (Supp. 1952).

${ }^{33} 205$ F. $2 d$ 706, 71 I (D. C. Cir. 1953), cert. granted, 346 U. S. 934 (1954).

36 P.U.R. (N.S.) 289 , at 318 . 
United States as a proper exercise of the conservation authority of the State. ${ }^{35}$ There can be no doubt that the Kansas order, as a lawful conservation measure within the competence of the Kansas Commission, stands on firm ground within the range of its proper application. But this does not-and cannot-mean that a state agency may by its action circumscribe the jurisdiction which the Congress has conferred upon this Commission to regulate the resale rates of natural gas which is transported and sold in interstate commerce.

In April, x954, the Federal Power Commission, in a complete reversal of its prior position, adopted the "Fair Field Price" method of pricing company-produced gas in setting rates for Panhandle Eastern Pipe Line Company. ${ }^{36}$ This method contemplates pricing such gas at the average of the prices paid for gas purchased from independent producers. This approach importantly affects the accounting treatment of various elements of cost of service, including production operating expenses, exploration and development costs, depletion, revenue from products-extraction, return assigned to the production function, and special tax benefits related to discovery and development of gas reserves. Because of the complexities of the application of this method and the differences in the circumstances of natural gas production of various pipeline companies, the final impact of this policy on rate regulation of the natural gas industry must await a fuller development of the issues presented by this method by valuing gas at the wellhead.

\section{B. Depreciation Expense}

Reduced to its simplest terms, an allowance for depreciation is an allowance for the "costs" of plant property and equipment consumed in the rendition of service. Among the many and varied controversial problems in the determination of an annual allowance for depreciation in rate proceedings are two salient aspects, often underemphasized or overlooked.

I. Tax Depreciation vs. Book Depreciation. Claiming depreciation for federal income tax purposes at substantially higher rates than are used for purposes of corporate books and financial statements raises potential problems from the regulatory viewpoint. That this problem is common to the public utility field is evidenced by a survey of 209 public utility companies for the year I95I, which showed that I52 claimed tax depreciation in excess of book depreciation.

The problems resulting from this practice are accentuated in the case of natural gas transmission companies which face a life limited by natural gas reserves owned or contracted for, or within economic reach of present lines. Assuming that book rates reflect the best estimate of useful life, depreciation claimed at a rate for tax purposes in excess of the rate used to record depreciation for book purposes, results in the current absorption of tax deductions applicable to future years. In other words, current tax reductions resulting from the excess of tax depreciation over book depreciation are not tax savings but are tax deferments.

${ }^{36}$ Cities Service Gas Co. v. Peerless Oil \& Gas Co., 340 U. S. I79 (1950); Phillips Petrolcum Co. v. Oklahoma, 340 U. S. I 90 (1950).

${ }^{30}$ Opinion No. 269, issued April $15,1954$. 
Under present rate-making principles followed by the Federal Power Commission wherein rates are based on an allowance for "actual taxes paid,"37 current tax reductions resulting from tax depreciation rates exceeding book depreciation rates are passed on to present consumers.

Since commissions generally have included "actual taxes payable" as an allowance in setting rates, it is likely that future rate payers will be required to pay the deferred income taxes; however, it must be considered that in accordance with established rate theories, future customers should not be required to subsidize present customers. On this basis, it is within the realm of possibility that this principle may be invoked by commissions in future rate proceedings as a basis for disallowing deferred income taxes represented by excess of tax depreciation rates over book depreciation rates. If this were done, shareholders would, in effect, then be paying for present tax deductions passed on to previous customers.

2. Impact of Changing Price Levels on Depreciation Allowance. The material decline in the purchasing power of the dollar during the war and postwar period has sharply accentuated the problems inherent in the determination of an allowance for depreciation.

The first purpose of an annual provision for depreciation is the recovery of the economic cost of the depreciable property consumed during the year. This economic cost is recovered only if the depreciation is sufficient to maintain the service capacity of the plant. The measure of this depreciation is the changing cost of the kind of property consumed by the utility.

The second purpose of the provision for depreciation is to maintain for the benefit of the investor the purchasing power of the capital committed to the enterprise, i.e., the recovery of equivalent capital in terms of dollars which have equal purchasing power to those originally committed to the enterprise. The appropriate measure of the depreciation to accomplish this purpose is the general change in the value of the dollar as distinguished from the changing cost of constructing the utility property.

The common method used by practically all regulatory bodies in the determination of the proper allowance for depreciation is amortization of original cost over the service life of the used and useful depreciable property. In times of stable currency, there is little doubt that depreciation on original cost is sound both on the basis of accounting methods in use and economic principles and is sufficient to maintain the service capacity of the plant and the purchasing power of the capital committed to the enterprise.

However, during periods of a drastic decline in the purchasing power of the dollar, as has occurred in the last decade, it is apparent that depreciation on original cost no longer serves to measure the economic cost of the property consumed in operations.

${ }^{37}$ Re Northern Natural Gas Co., 95 P.U.R. (N.s.) 289 (1952); Re Transcontinental Gas Pipe Line Corporation, 94 P.U.R. (N.s.) 335, 351 (1952); Re Mississippi River Fuel Corp., 63 P.U.R. (N.s.) $89,97(1946)$. 
In unregulated business, the price levels in a competitive market tend to move to the levels at which products may be sold by a new competitor, produced by a plant built at current costs and, therefore, the selling price reflects the economic cost of depreciation of the plant. In the regulated field, however, costs and a fair return on investment are the only criteria for setting prices. If certain economic costs are disregarded, it is obvious that the utility runs the risk of underpricing its product and undermining service to the public.

In spite of the apparent simplicity of the problem, most regulatory commissions, including those which recognize fair value in the rate base, remain on an original cost basis for the calculation of depreciation requirements.

The reluctance of regulatory bodies to recognize the erosive results of original cost depreciation on equity interests can perhaps be traced in part to the impact of accounting techniques on rate proceedings. While the great majority of accountants recognize that conventional methods of recording amortization of original cost fail to recognize the economic cost of depreciation, irreconcilable controversies have arisen in the accounting profession as to what should be done about the problem in formal accounting statements. This fact, together with the failure of current tax laws to recognize the effects of inflation in allowances for depreciation, has undoubtedly had a deterring influence on the recognition of economic depreciation for rate-making purposes.

It cannot be denied, however, that irrespective of the accounting or tax treatment afforded economic depreciation, the recovery by the investor of prewar investments in terms of 1954 dollars can only result in dilution of equity interest. Contrary to the contentions of certain advocates for recognition of economic depreciation, however, it does not appear equitable to allow current cost depreciation on the entire investment nor is this required to maintain the integrity of the enterprise. That portion of the investment represented by borrowed money is repaid in terms of the original dollars in accordance with the debt contract. Recovery of current cost depreciation on investment represented by debt capital can only revert to the stockholder. It is evident, therefore, in the interests of both investor and consumer, that regulatory recognition of the changing price levels if considered at all will be considered in the determination of the allowance for depreciation, only to the extent of the stockholders' interest in the total investment. It is also evident that until regulatory bodies give serious consideration to the effect of inflation in rate-making proceedings, the continuous erosion of owners' capital will continue to undermine the stability of the enterprise with the resultant danger to future service to the consumer.

\section{Aliocation of Cost of Service}

A discussion of public utility rate-making invariably returns to the principle that rates should be set, as nearly as possible, at a level which would prevail if the utility company operated under competitive restraints. This principle is basic, at 
least to the accounting approach, because the data available for evaluation of a reasonable level of rates are necessarily limited to the costs actually incurred or anticipated in rendering utility service. These costs are taken to represent, with some reservations which are not important here, the same costs as would be incurred by a hypothetical competitor who is awaiting entry into the market. The rates in the aggregate, therefore, need be no more than the costs in the aggregate to enable an existing utility company to enjoy treatment similar to that which might be accorded in a competitive environment. ${ }^{38}$

The logic of this approach seems to imply that the determination of specific rates for individual or groups of customers involves nothing more than a refinement or allocation of the same data used to determine the level of rates in the aggregate. The additional problem simply involves the development of appropriate bases and techniques for the apportionment of costs among customers. While the logical approach to historical data may be fairly clear, the use of these data in fixing rates for the future is not nearly so simple. The refinement of costs in the aggregate requires many assumptions of static relationships both as to elements of cost and as to customer responsibility for demand of the service. In fact, these relationships change rapidly, rarely follow discernible trends, and, indeed, are often strongly influenced by changes in the rate structure which are designed to reflect their very demand and cost relationships.

It is not the purpose of this article to comment on the economic or social consequences of the use of cost allocations in rate-making, especially as these allocations are applied to service areas and customer classifications. It will be apparent, however, from a discussion of the accounting problems of cost allocation that the usefulness of allocation techniques is seriously limited and that the data which are accumulated can be used for advisory purposes only.

The employment of cost allocation techniques in rate proceedings received initial impetus in the early court cases involving jurisdictional limitations of state regulatory authorities. In brief, these cases established the rule that the jurisdiction of a state commission is limited to the business done within its boundaries and that, whatever the technical difficulties, the findings must include an apportionment of property and expenses of a utility company whose operations cross state boundaries. Moreover, such apportionments must be based on allocation factors which measure the relative use of the utility facilities in the various jurisdictional areas. ${ }^{39}$

\footnotetext{
${ }^{38}$ Regulatory bodies have not required cost of service studies for specific customers in a proceeding for a general revenue increase except in extraordinary situations. The Illinois Supreme Court sustained the Illinois Commission in refusing to require such studies for consideration of a rate increase that followed historical patterns, even in a proceeding which involved specific rate schedules rather than a general revenue increase. Produce Terminal Corp. v. Illinois Commerce Comm'n, 414 Ill. 582, II2 N. E. 2d $\times 4$ I (1953). The Superior Court of Pennsylvania sustained the refusal of the Pennsylvania commission to require cost allocation studies under a statutory prohibition of unreasonable discrimination similar to Illinois. City of Pittsburgh v. Pennsylvania Public Utility Comm'n, I7I Pa. Super. I87, 90 A. $2 \mathrm{~d} 607,621$ (1952).

${ }^{30}$ The Minnesota Rate Cases, 230 U. S. 352 (I913); Smith v. Illinois Bell Telephone Co., 282 U. S. r33 (1930).
} 
As jurisdictional issues and rate problems have grown in complexity over the years, accounting evidence involving allocations of cost of service has been developed primarily in four general areas of the rate-making process:

(I) allocations between geographical or jurisdictional subdivisions of a system;

(2) allocations between utility departments in a combination company;

(3) allocations between various classes of customers who are responsible for differing demands upon the utility service; and,

(4) allocations between types of costs, shared in varying proportions by different service classifications, as the basis for the design of the rate structure and the form of rates.

Rate regulation of natural gas utility companies brings into play all of these allocation requirements. The organization and operating characteristics of the gas industry, however, place most emphasis upon the allocation techniques which may be used to apportion joint costs to various customer classifications. The jurisdiction of the Federal Power Commission is defined in terms of territory (interstate commerce) and customers served (sales for resale) with the latter of primary importance in cases involving natural gas pipelines. ${ }^{40}$

The accounting applications in cost allocations are, of course, conditioned upon operating and engineering data with respect to load characteristics and customer responsibility for demand on the utility system. Each case has its own special prob: lems. The basic accounting approach adopted by the Federal Power Commission, however, has been rigid in application and has seldom varied with special situations. This approach requires grouping of operating expenses and costs of facilities by service "functions." Generally, these functions have been classified as natural gas production and gathering (including gas purchased and produced), long distance transmission, and delivery from the main transmission line to customers' premises.

Unless special circumstances warrant individual treatment, gas procured from various sources and intermingled in the main transmission line is assigned an average cost to all customers. Miscellaneous revenues from products extracted from natural gas by others are generally credited against the cost of gas production. The treatment of revenues from the company's own products' extraction operations, however, varies with individual cases. The costs of gas supplied from the utility company's own production facilities are generally classified as commodity or volume costs. Within certain broad limitations, these costs vary upward and downward with deliveries of gas from the fields. The costs of purchased gas are not, however, uniformly related to "take," and the classification to commodity is conditioned both upon the terms of purchase and the utility company's ability to adapt its load to whatever demand requirements may be contained in the gas purchase contract.

Transmission costs are classified to demand and commodity components on the assumption that the final allocations to firm and interruptible customers, respectively, ${ }^{10}$ The Natural Gas Act, 52 Stat. 821-833 (1938), as amended, 15 U. S. C. \$\$717-717w (Supp. x952). 
should reflect an assignment of a larger share of fixed or "capacity" costs to the firm customers who are entitled to preferential use of pipeline capacity during the winter season. Certain expenses, such as compressor fuel and supplies (commodity) may be assigned directly to the proper cost component on the basis of their relationship to flow of gas through the lines. However, the largest portion of transmission expenses-notably: depreciation; income, property, and other general taxes; and return -are joint as to demand and commodity. Such expenses can be classified only on the basis of an exhaustive study of pipeline operations, or on the basis of "expert judgment." The Federal Power Commission has consistently held to a "judgment" allocation of $5^{\circ}$ per cent to demand and $5^{\circ}$ per cent to commodity, and has repeatedly rejected studies presented by expert witnesses who were eminently qualified in the industry, and who have repeatedly recommended allocations of a larger-than50 per cent share of joint costs to demand. Moreover, the Commission has shown a strong reluctance to accept allocations based on specific use of utility property by specific customers.

City gate and main line industrial measuring and regulating station property and expenses and the costs of local distribution generally do not involve complex allocation problems. Assignment of cost of service of these functions may, in most cases, be made directly to the service areas or to customers from the books and records of the utility company, or on a simple unit allocation basis.

The completed separation method involves basic allocations to functions and reallocations within functions to demand and commodity components. The most apparent effect of this allocation process is to disseminate the identity of joint costs, and to place final emphasis upon the relationship between the total unit costs of gas delivered to various classes of customers. The test of reasonableness of this allocation process necessarily must lie in the comparison of unit costs, rather than in the validity of the basic assumptions employed in the allocations themselves. It must be apparent to even the most casual observer that the accounting responsibility of the arbitrary allocation method currently used by the Federal Power Commission is neither basic nor susceptible to development and improvement. The realignment of "costs" and resulting changes in cost of service to various classes of customers comes about automatically with each expression of "judgment" as to the proper distribution of the joint costs of operation. It would seem extremely doubtful that important and improved allocation developments will occur in the regulation of interstate gas pipeline companies until the basic approach to allocation problems is open to revaluation in the light of each applicant's circumstances.

\section{RATE OF RETURN}

Rate of return is a judgment percentage which will yield a reasonable annual return to those who have capital invested in the utility enterprise. If an investmenttype rate base is used, the over-all cost of capital is indicative of the minimum rate of return required. Recent decisions of the Federal Power Commission have fol- 
lowed the "cost of capital" approach in determining allowable rate of return for natural gas companies. While the Commission has avoided an inflexible formula in arriving at rate of return, the cost of capital type of evidence has been given predominant weight in findings and orders.

The cost of debt and preferred stock capital is generally expressed as a percentage of the annual contractual interest or dividend requirements to the specific funds obtained for permanent investment in utility facilities. The cost of common stock capital is expressed as a ratio of current earnings to current market prices, and, together with an allowance for cost of flotation, is represented as the cost to attract new equity capital. The tendency in staff presentations is to present the historical debt and preferred stock capital costs as certain and inflexible costs incurred in the business before an allowance for common equity capital. Such an approach has been strongly resisted by utility companies and independent experts in the financial field, and one of the most recent expressions of the Commission has reaffirmed the necessity of flexibility in the determination of over-all rate of return. There is, of course, a strong appeal to the argument that return should be based on amounts actually required to meet contractual interest and dividend costs. Whatever is not required to pay these costs in any particular period of operations accrues to the common equity interest, and theoretically is not "required" to service capital. The problem, however, is not so simple.

Rate of return can only be determined by informed and considered judgment. The emphasis upon statistical data and arithmetical computations not only limits the scope of such judgment, but tends to "freeze" the allowable return to reflect existing capital structure and historical debt costs. Such determinations leave no room for improvement of capital structure or credit rating, and in fact may close the door to credit in an emergency. It would appear that strict accounting or statistical analyses with respect to cost-of-money calculations should be entitled to limited weight in rate-of-return determinations. 